\title{
Virulence profiling of Shiga toxin-producing Escherichia coli recovered from domestic farm animals in Northwestern Mexico
}

\author{
Bianca A. Amézquita-López ${ }^{1}$, Beatriz Quiñones ${ }^{2 *}{ }^{*}$ Bertram G. Lee $^{2}$ and Cristóbal Chaidez ${ }^{\text {* }}$ \\ ${ }^{1}$ Centro de Investigación en Alimentación y Desarrollo, Culiacán, Mexico \\ 2 Produce Safety and Microbiology Research Unit, U.S. Department of Agriculture/Agricultural Research Service, Western Regional Research Center, Albany, \\ CA, USA
}

\author{
Edited by: \\ Nora L. Padola, Universidad Nacional \\ del Centro de la Provincia de \\ Buenos Aires, Argentina \\ Reviewed by: \\ Mauricio Farfan, University of Chile, \\ Chile \\ Paula M. A. Lucchesi, Universidad \\ Nacional del Centro de la Provincia \\ de Buenos Aires, Argentina

\section{*Correspondence:} \\ Beatriz Quiñones, Produce Safety \\ and Microbiology Research Unit, \\ USDA/ARSMRRC, 800 Buchanan \\ Street, WAB 214L, Albany, \\ CA 94710, USA \\ e-mail: beatriz.quinones@ \\ ars.usda.gov; \\ Cristóbal Chaidez, Centro de \\ Investigación en Alimentación y \\ Desarrollo, Carretera a El Dorado \\ Km5.5, Col. Campo El Diez, \\ Culiacán, Sinaloa 80111, México \\ e-mail: chaqui@ciad.edu.mx
}

Shiga toxin-producing Escherichia coli (STEC) is a zoonotic enteric pathogen that causes human gastrointestinal illnesses. The present study characterized the virulence profiles of 0157 and non-0157 STEC strains, recovered from domestic animals in small rural farms within the agricultural Culiacan Valley in Mexico. Virulence genes coding for adhesins, cytotoxins, proteases, subtypes of Shiga toxin (Stx), and other effectors were identified in the STEC strains by PCR. The genotyping analysis revealed the presence of the effectors $n l e A$, nleB, nleE, and nleH1-2, espK, and espN in the O157:H7 and 0111:H8 STEC strains. Furthermore, the genes encoding the autoagglutinating adhesin (Saa) and subtilase (SubA) were exclusively identified in the O8:H19 eae-negative strains. The adhesin (iha) and the silent hemolysin (sheA) genes were detected in 79\% of the 0157 and non-0157 strains. To examine the relative toxicities of the STEC strains, a fluorescent Vero cell line, Vero-d2EGFPs, was employed to measure the inhibition of protein synthesis by Stx. Analysis of culture supernatants from serotype O8:H19 strains with the stx gene profile $s t x_{1 a}, s t x_{2 a}$, and $s t x_{2 c}$ and serotypes O75:H8 and 0146:H8 strains with the stx gene profile $s t x_{1 a}, s t x_{1 c}$, and $s t x_{2 b}$, resulted in a significant reduction in the Vero-d2EGFP fluorescent signal. These observations suggest that these non-0157 strains may have an enhanced ability to inhibit protein synthesis in Vero cells. Interestingly, analysis of the stx $2 \mathrm{c}$-positive 0157:H7 strains resulted in a high fluorescent signal, indicating a reduced toxicity in the Vero-d2EGFP cells. These findings indicate that the 0157 and non-O157 STEC strains, recovered in the Culiacan Valley, display distinct virulence profiles and relative toxicities in mammalian cells and have provided information for evaluating risks associated with zoonotic STEC in this agricultural region in Mexico.

Keywords: Escherichia coli, STEC, virulence genes, Shiga toxin, Vero cells, Mexico, zoonosis, foodborne pathogen

\section{INTRODUCTION}

Shiga toxin-producing Escherichia coli (STEC) is considered to be a major cause of foodborne disease and can cause a wide variety of disease symptoms in humans, ranging from watery and bloody diarrhea to the life-threatening diseases such as hemorrhagic colitis, and hemolytic uremic syndrome (HUS) (Tarr et al., 2005; Gyles, 2007; Karmali et al., 2010; Scallan et al., 2011; Melton-Celsa et al., 2012). Cattle are considered to be the major carrier of STEC strains (Gyles, 2007; Ferens and Hovde, 2011). However, additional studies that examined important animal reservoirs for these bacterial pathogens have indicated that small domestic ruminants, including sheep and goats, have been implicated as carriers of STEC (Ogden et al., 2005; Gyles, 2007; La Ragione et al., 2009; Ferens and Hovde, 2011; Mandrell, 2011). Furthermore, STEC strains have been also detected in other domestic and wild animals, including cats, dogs, rodents, deer, birds, feral pigs, chickens, and insects (Cooley et al., 2007; Ferens and Hovde, 2011; Mandrell, 2011).
Severe disease in humans has been associated with more than 100 serotypes of STEC (Gould et al., 2009; Mathusa et al., 2010). Serotype O157:H7 is responsible for most outbreaks in the United States (Karmali, 2009; Hoefer et al., 2011; Melton-Celsa et al., 2012). Additional epidemiological studies have indicated that six non-O157 serogroups, O26, O45, O103, O111, O121, and O145, have been associated with severe disease symptoms in North America (Johnson et al., 2006; Gould et al., 2009; Stigi et al., 2012). Additionally, STEC of serogroups, O91, O104, O113, and O128 have been reported to be significant causes of human infections worldwide (Brooks et al., 2005; Bettelheim, 2007; Mathusa et al., 2010; Beutin and Martin, 2012). Thus, these findings have indicated that strains with certain non-O157 serogroups may be potentially as virulent as strains with the O157:H7 serotype (Bettelheim, 2007; Coombes et al., 2011; Beutin and Martin, 2012; Stigi et al., 2012).

The production of Shiga toxins (Stx) by STEC contributes to the development of the life-threatening disease symptoms in humans (Karmali et al., 1983; Karmali, 1989). The Stx family 
has been categorized into two major types, Stx1 and Stx2. In particular, distinct subtypes of Stx1, Stxla, Stx1c and Stx1d, have been identified (Scheutz and Strockbine, 2005; Scheutz et al., 2012). By contrast, the Stx 2 group consists of a heterogeneous and diverse group of subtypes, and seven subtypes of Stx2, corresponding to Stx2a, Stx2b, Stx2c, Stx2d, Stx2e, Stx2f, and Stx2g, have been documented (Scheutz and Strockbine, 2005; Scheutz et al., 2012). Epidemiological and molecular genotyping studies of STEC have demonstrated that there is a strong correlation between strains with certain $s t x_{2}$ subtypes and severe illness such as bloody diarrhea and HUS. STEC strains positive for the subtypes $s t x_{2 a}$, stx $2 c$, or $s t x_{2 d}$ were found to be associated with an enhanced virulence and with the development of the HUS in humans (Friedrich et al., 2002; Beutin et al., 2004; Bielaszewska et al., 2006; Persson et al., 2007). Other subtypes of Stx1 and Stx2 appear to be associated with mild disease or asymptomatic carriage (Friedrich et al., 2002, 2003; Beutin et al., 2004; Bielaszewska et al., 2006; Scheutz et al., 2012).

Many STEC strains that produce Stx do not cause HUS, demonstrating that additional virulence factors may be required to cause illness in humans (Bolton, 2011). For example, virulence factors present on pathogenicity islands, such as the locus of enterocyte effacement (LEE) and the non-LEE effectors, have been implicated in host colonization and disease (Bettelheim, 2007; Bolton, 2011; Coombes et al., 2011). In particular, a key virulence factor responsible for the attachment to intestinal epithelial cells is the LEE-encoded eae gene (Jerse et al., 1990; Kaper, 1998). An additional adhesin, Iha, the iron-regulated gene A homolog adhesin, may contribute to the attachment of LEE-positive and LEE-negative strains (Tarr et al., 2000; Schmidt et al., 2001). Moreover, the Nle effectors, not encoded by the LEE region, are proposed to be involved in altering the host cell response and have been linked to the disease severity associated with non-O157 STEC (Coombes et al., 2008; Karmali et al., 2010; Melton-Celsa et al., 2012). Other chromosomal and plasmid virulence genes, encoding proteases (espP), cytotoxins $(s u b A)$, and adhesins (saa), may contribute to STEC pathogenesis by allowing bacterial attachment and colonization of the human epithelium (Karmali et al., 2010; Bolton, 2011; Melton-Celsa et al., 2012). The detection of these virulence genes in STEC strains would provide key information for the identification of risk factors that may potentially contribute to the development of human disease.

In the present study, a molecular characterization study was conducted to further examine the virulence potential of STEC strains, previously recovered from feces of domestic animals in small rural farms within the agricultural Culiacan Valley in Northwestern Mexico (Amézquita-López et al., 2012). The small rural farms were located in communities where the primary purpose of raising livestock is for local consumption (Amézquita-López et al., 2012). To determine the virulence profiles of STEC strains from animal reservoirs in this agricultural region in Mexico, the present study identified the stx subtypes as well as several virulence factors that have been associated with pathogenic STEC strains. The activity of the Stx subtypes, expressed by the tested STEC strains, was also further examined to obtain more detailed information on their ability to inhibit protein synthesis in mammalian cells.

\section{MATERIALS AND METHODS BACTERIAL STRAINS AND GROWTH CONDITIONS}

A subset of 29 STEC strains, previously recovered from various animal reservoirs in the Culiacan Valley in Mexico (AmézquitaLópez et al., 2012), was studied (Table 1). The subset of strains was selected based on serotype and on the recovery from distinct dates, sampling sites and animal reservoirs (Amézquita-López et al., 2012).

The method employed to isolate the STEC strains (Table 1) from fecal samples from various domestic animals was previously described (Amézquita-López et al., 2012). The characteristics and

\section{Table 1 | List of E. coli 0157 and non-0157 strains analyzed in this study.}

\begin{tabular}{|c|c|c|c|c|}
\hline Strain & Serotype $^{a}$ & Sampling date & Source & Region $^{b}$ \\
\hline RM8744 & O157:H7 & 18-Nov-08 & Cattle & Iraguato \\
\hline RM8745 & O73:H4 & 02-Dec-08 & Sheep & El Castillo \\
\hline RM8747 & O15:NT & 22-Jul-08 & Cattle & Agua Caliente \\
\hline RM8748 & O73:NT & 22-Jul-08 & Cattle & Agua Caliente \\
\hline RM8749 & $\mathrm{O} 20: \mathrm{H} 4$ & 12-Aug-08 & Sheep & El Castillo \\
\hline RM8752 & O75:H8 & 07-Oct-08 & Sheep & Cofradia de Navolato \\
\hline RM8753 & O157:H7 & 02-Dec-08 & Sheep & Cofradia de Navolato \\
\hline RM8755 & O111:H8 & 20-Jan-09 & Sheep & Cofradia de Navolato \\
\hline RM8756 & $\mathrm{O} 146: \mathrm{H} 21$ & 20-Jan-09 & Sheep & Jotagua \\
\hline RM8759 & 0157:H7 & 20-Jan-09 & Sheep & Cofradia de Navolato \\
\hline RM8760 & O75:H8 & 20-Jan-09 & Sheep & Cofradia de Navolato \\
\hline RM8761 & $\mathrm{O} 146: \mathrm{H} 21$ & 20-Jan-09 & Sheep & El Castillo \\
\hline RM8762 & 0146:H8 & 20-Jan-09 & Sheep & El Castillo \\
\hline RM8763 & O75:H8 & 03-Feb-09 & Sheep & Cofradia de Navolato \\
\hline RM8768 & O157:H7 & 20-Jan-09 & Cattle & Cofradia de Navolato \\
\hline RM8772 & O8:H19 & 17-Feb-09 & Cattle & El Castillo \\
\hline RM8776 & O8:H19 & 03-Feb-09 & Cattle & Iraguato \\
\hline RM8778 & O75:H8 & 25-Feb-09 & Sheep & Cofradia de Navolato \\
\hline RM8781 & O157:H7 & 25-Feb-09 & Sheep & Cofradia de Navolato \\
\hline RM8922 & O157:H7 & 10-Mar-09 & Cattle & Cofradia de Navolato \\
\hline RM8923 & O75:H8 & 10-Mar-09 & Cattle & Cofradia de Navolato \\
\hline RM8928 & O157:H4 & 10-Mar-09 & Cattle & El Castillo \\
\hline RM8929 & O75:H8 & 10-Mar-09 & Sheep & Cofradia de Navolato \\
\hline RM9450 & O157:H7 & 10-Mar-09 & Sheep & Cofradia de Navolato \\
\hline RM9452 & O157:H7 & 26-May-09 & Sheep & Cofradia de Navolato \\
\hline RM9454 & O157:H7 & 26-May-09 & Cattle & Cofradia de Navolato \\
\hline RM9456 & O157:H7 & 07-Apr-09 & Cattle & Cofradia de Navolato \\
\hline RM9458 & O157:H7 & 24-Mar-09 & Chicken & Agua Caliente \\
\hline RM9462 & O157:H7 & 03-Jun-09 & Cattle & Iraguato \\
\hline RM13865 & O75:H8 & 07-Apr-09 & Cattle & Cofradia de Navolato \\
\hline
\end{tabular}

${ }^{a} N T$, Non-typeable H-antigen.

${ }^{b}$ Sampling sites correspond to regions in the Culiacan Valley, Sinaloa, Mexico (Amézquita-López et al., 2012). 
sources of the STEC reference strains that were used in this study are described in Table 2 . Bacteria were routinely propagated under aerobic conditions at $37^{\circ} \mathrm{C}$ on Luria-Bertani (LB) agar (Difco, Detroit, MI).

\section{POLYMERASE CHAIN REACTION FOR AMPLIFICATION OF stx SUBTYPES AND OTHER VIRULENCE GENES}

For the detection of stx subtypes and other virulence genes, the following STEC reference strains (Table 2) were used as a control for the PCR amplification of ent/espL2, espK, espN, espP, etpD, ihA, katP, nleA, nleB, nleE, nleH1-2, sheA, stx $x_{1 \mathrm{a}}$, and $s_{x_{2 \mathrm{a}}}(\mathrm{RM} 2084) ;$ stx $_{2 \mathrm{c}}(\mathrm{RM} 7004) ;$ stx $_{2 \mathrm{~b}}$ (RM7005); saa and $s t x_{2 \mathrm{~d}}$ (RM7006); stx $2 \mathrm{f}$ (RM7007); stx $x_{2 \mathrm{e}}$ (RM7110); stx $2 \mathrm{~g}$ (RM7203); stx $1 \mathrm{~d}$ (RM7369); stx $1 \mathrm{c}$ (RM7508); hlyA (RM10227). All PCR amplifications were performed by using primers as shown in Table 3. As template for the PCR reaction, cultures of the STEC strains were grown aerobically in tryptic soy broth (Beckton Dickinson, Sparks, MD) for $24 \mathrm{~h}$ with constant shaking $(200 \mathrm{rpm})$ at $37^{\circ} \mathrm{C}$, and $100 \mu \mathrm{L}$ of the bacterial cultures were collected by centrifugation at $2000 \times g$ for $5 \mathrm{~min}$. Cell pellets were resuspended in $100 \mu \mathrm{l}$ of $\mathrm{HyPure}^{\mathrm{TM}}$ molecular biology-grade water (HyClone Laboratories, Inc., Logan, UT) and incubated at $95^{\circ} \mathrm{C}$ for $20 \mathrm{~min}$, as in previous studies (Quiñones et al., 2011, 2012). The lysates were centrifuged at $2000 \times g$ for $5 \mathrm{~min}$, and the supernatants were collected and frozen until further use. The PCR amplifications consisted of a $25 \mu \mathrm{l}$ reaction mixture, each containing $5 \mu \mathrm{L}$ of the bacterial crude lysate, $0.5 \mu \mathrm{M}$ of each primer (Eurofins MWG Operon, Huntsville, AL), and $12.5 \mu$ l of $2 \times$ GoTaq $^{\circledR}$ Green Master Mix (Promega Corporation, Madison, WI). The reaction mixtures were placed in a Dyad Peltier Thermal Cycler (Bio-Rad Laboratories, Hercules, CA), as in previous studies (AmézquitaLópez et al., 2012). The virulence genes were amplified with PCR cycling conditions, as described in the references listed in Table 3. Amplified products were analyzed in 2\% agarose gels containing $0.04 \mu \mathrm{l} / \mathrm{ml}$ GelRed Nucleic Acid Stain (Phenix Research, Candler, NC).

\section{VERO CELL-BASED METHOD TO DETECT STX ACTIVITY}

The Stx activity of the STEC strains was measured using a Vero cell line, Vero-d2EGFP, that harbored a destabilized variant $\left(t_{1 / 2}=2 \mathrm{~h}\right)$ of the enhanced green fluorescent protein (EGFP) (Quiñones et al., 2009; Quiñones and Swimley, 2011). To monitor the Stx-induced inhibition of protein synthesis, the tested STEC strains (Table 1), the Stx-expressing O157:H7 strain RM2084 (positive control) (Table 2), and the Stx-negative O157:H4 strain RM8928 (Amézquita-López et al., 2012) (negative control) were inoculated in $1 \mathrm{ml}$ of sterile LB broth (Difco, Detroit, MI). All E. coli strains were grown aerobically for $24 \mathrm{~h}$ at $37^{\circ} \mathrm{C}$ with shaking at $200 \mathrm{rpm}$ and were then centrifuged at $2000 \times g$ for $15 \mathrm{~min}$. The culture supernatants were filter-sterilized using $0.45 \mu \mathrm{m}$ polyvinylidene fluoride syringe filters (Durapore ${ }^{\circledR}$ membranes, Millipore Corporation, Billerica, MA) and were frozen at $-20^{\circ} \mathrm{C}$ until further use (Quiñones and Swimley, 2011). One day prior to intoxication, the Vero-d2EGFP cells were seeded at 10,000 cells per well in Greiner black 96-well microplates with clear bottoms (VWR International, Aurora, CO) and were grown at $5 \% \mathrm{CO}_{2}$ and $37^{\circ} \mathrm{C}$ under humidified conditions in Ham's F-12 complete medium, supplemented with $10 \%$ fetal bovine serum and $1 \%$ penicillin-streptomycin (Gibco BRL, Grand Island, NY) (Quiñones et al., 2009; Quiñones and Swimley, 2011). The Vero-d2EGFP cells were then exposed to Ham's F-12 complete medium containing a tenfold dilution of the cell-free supernatants from each strain and were incubated for $16 \mathrm{~h}$ at $37^{\circ} \mathrm{C}$ in a $5 \% \mathrm{CO}_{2}$ humidified incubator. The EGFP fluorescence from the Vero-d2EGFP cells was measured using a Synergy HT MultiDetection Microplate Reader (BioTek, Winooski, VT) with the $485 / 20 \mathrm{~nm}$ excitation filter and the $528 / 20 \mathrm{~nm}$ emission filter (Quiñones et al., 2009; Quiñones and Swimley, 2011). All measurements were performed in triplicate, and the results were expressed as percentages of the fluorescence values obtained for culture supernatant-treated Vero-d2EGFP cells when compared to the fluorescence values from control Vero-d2EGFP cells incubated without culture supernatants. To determine statistical differences in the Stx activity among the STEC strains,

Table 2 | Shiga toxin-producing Escherichia coli reference strains used in this study.

\begin{tabular}{llllll}
\hline Strain & Other strain designations & Serotype & Source & Location & Provider or reference $^{\mathbf{a}}$ \\
\hline RM2084 & EDL-933; DEC 4f & O157:H7 & Meat & United States & ECRC (Reid et al., 1999) \\
RM7004 & E32511; TW02883 & O157:H & Human & United States & The STEC Center (Schmitt et al., 1991) \\
RM7005 & EH250; TW081611 & O118:H12 & Human & Belgium & The STEC Center (Piérard et al., 1998) \\
RM7006 & B2F1; TW01393 & O91:H21 & Human & Canada & The STEC Center (Ito et al., 1990) \\
RM7110 & NADC2228; S1191 & O139:NM & Pig & United States & Evelyn Dean-Nystrom (Weinstein et al., 1988) \\
RM7203 & SC-0012 & O168:H8 & Coyote & United States & Michael B. Cooley (Cooley et al., 2013) \\
RM7369 & SP-0082-G9 & ONT:H7 & Pig & United States & Michael B. Cooley (Cooley et al., 2013) \\
RM7508 & MA146B-A7 & O128:H2 & Deer & United States & Michael B. Cooley (Cooley et al., 2013) \\
RM7519 & F260-H2 & O113:H21 & Cattle & United States & Michael B. Cooley (Cooley et al., 2013)
\end{tabular}

${ }^{a}$ Contact information of strain providers: ECRC, E. coli Reference Center, College of Agricultural Sciences, The Pennsylvania State University, University Park, PA, USA; The STEC Center, National Food Safety and Toxicology Center, Michigan State University, East Lansing, MI, USA; Michael B. Cooley, USDA/ARS, Western, Regional Research Center, Produce Safety and Microbiology Research Unit, Albany, CA, USA; Evelyn Dean-Nystrom, lowa State University, National Animal Disease Center, Veterinary Microbiology and Preventive Medicine, Ames, lowa, USA. 
Table 3 | List of DNA oligonucleotides used in this study for PCR amplification.

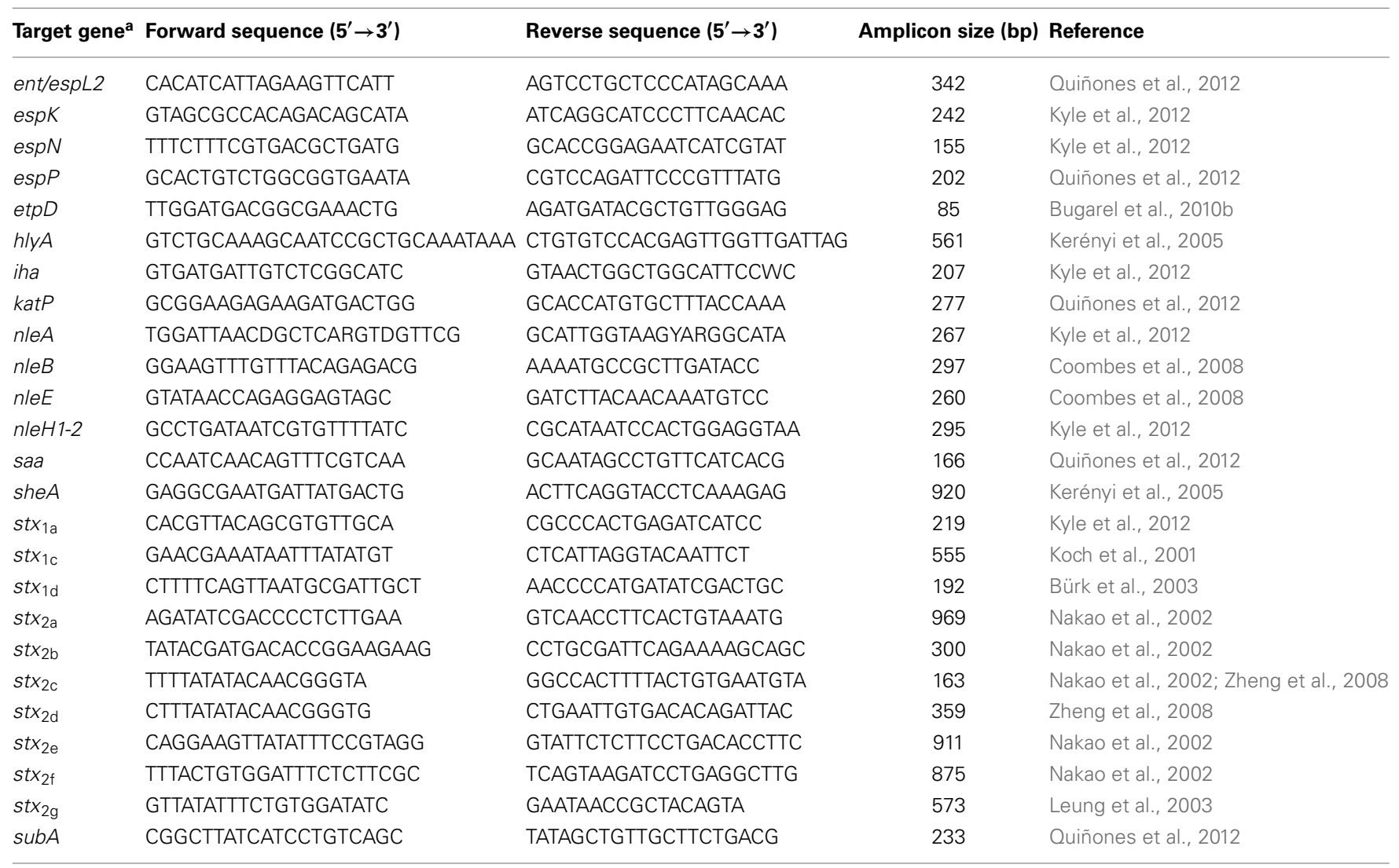

${ }^{a}$ The stx 1 and stx 2 subtypes are listed with new stx nomenclature, as recently described (Feng et al., 2011; Scheutz et al., 2012)

the results were analyzed by performing a $k$-means clustering using the Hartigan and Wong algorithm (Hartigan and Wong, 1979) with the R Statistical Software (version 3.0.1; R Foundation for Statistical Computing, Vienna, Austria) (R-Core Team, 2013). The distinct clusters were further validated by measuring the Dunn Index with the clValid R Package (Brock et al., 2008).

\section{RESULTS}

\section{VIRULENCE GENE PROFILES OF STEC STRAINS FROM DOMESTIC FARM ANIMALS}

To further characterize the virulence potential of STEC strains recovered from domestic farm animals in the agricultural Culiacan Valley region in Mexico, the presence of genes, associated with pathogenic STEC strains, was identified. Our initial analysis focused on the identification of the subtypes of Stx, a virulence factor that has been attributed to the development of serious disease symptoms in humans (Karmali et al., 2010; Bolton, 2011; Melton-Celsa et al., 2012). The results indicated that $97 \%(28 / 29)$ of the O157 and non-O157 STEC strains, recovered from sheep, cattle and chickens, were PCR-positive for genes encoding stx 2 subtypes (Table 4). By contrast, st $x_{1}$ subtypes were only identified in the non-O157 strains from sheep and cattle. Interestingly, the $s t x_{2 c}$ subtype was detected in
$51 \%(15 / 29)$ of the strains selected from the different animal sources and was predominantly identified in strains with the O157:H7 serotype (Table 4). Furthermore, the stx $2 \mathrm{~d}$ subtype was only identified in the ovine strain RM8749 belonging to serotype O20:H4. Our results also demonstrated that 45\% (13/29) of the recovered STEC strains were positive for more than one gene encoding stx subtypes in the same strain. In particular, strains with serotypes O73:H4, O75:H8, O146:H8, and O146:H21 were found to harbor the $s t x$ gene profile $s t x_{1 \mathrm{a}}$, $s t x_{1 \mathrm{c}}$, and $s t x_{2 \mathrm{~b}}$ (Table 4). Moreover, the stx gene profile $s t x_{1 \mathrm{a}}$, $s t x_{2 \mathrm{a}}$, and $s t x_{2 \mathrm{c}}$ was exclusively found in the O8:H19 strains recovered from cattle. None of the STEC strains recovered from domestic animals in rural farms in the Culiacan Valley were PCR-positive for the stx subtypes $s t x_{1 \mathrm{~d}}$, stx $x_{2 \mathrm{e}}$, st $x_{2 \mathrm{f}}$, or st $x_{2 \mathrm{~g}}$.

Given that Stx is not the only virulence determinant that is responsible for full pathogenicity (Karmali et al., 2010; Bolton, 2011; Melton-Celsa et al., 2012), the STEC strains isolated from this agricultural region were further screened for the presence of additional markers encoding adhesins, cytotoxins, proteases, and other effectors. The virulence typing analysis revealed the presence of the non-LEE encoded effectors, nleA, nleB, nleE, and nleH1-2, in the recovered O157:H7 strains from sheep, cattle, and chicken as well as in the recovered O111:H8 strains from sheep 
(Table 4). Other effectors, espK, and espN, were also identified in the O157:H7 and O111:H8 strains. However, the plasmidencoded etpD gene was only detected in the O157:H7 strains. Furthermore, saa and $s u b A$ genes were exclusively identified in the O8:H19 cattle strains (Table 4). Finally, the iron-regulated adhesion gene (iha) and the cytolysin A gene (sheA) were both present in 79\% (23/29) of the non-O157 and O157 strains. The ovine strains belonging to serotypes O20:H4 and O73:H4 were found to be negative for the presence of the accessory Table 4 | Identification of virulence genes in E. coli 0157 and
non-0157 strains used in this study.

\begin{tabular}{|c|c|c|c|}
\hline Serotype & Strain & Source & Virulence profile \\
\hline \multirow[t]{2}{*}{ O8:H19 } & RM8772 & Cattle & \multirow{2}{*}{$\begin{array}{l}\text { espP, saa, stx } 1 a, s t x_{2 a} \\
s t x_{2 c}, \text { subA }\end{array}$} \\
\hline & RM8776 & Cattle & \\
\hline O15:NT & RM8747 & Cattle & $\begin{array}{l}\text { ent/espL2, espP, katP, } \\
\text { stx }_{2 c}\end{array}$ \\
\hline $\mathrm{O} 20: \mathrm{H} 4$ & RM8749 & Sheep & stx $2 \mathrm{~d}$ \\
\hline O73:NT & RM8748 & Cattle & $\begin{array}{lll}\text { ent/espL2, espP, katP, } & \text { stx } \\
\text { sta } & & \end{array}$ \\
\hline O73:H4 & RM8745 & Sheep & $s t x_{1 a}, s t x_{1 c}, s t x_{2 b}$ \\
\hline \multirow[t]{7}{*}{ O75:H8 } & RM8752 & Sheep & \multirow{7}{*}{$\begin{array}{l}\text { iha, sheA, stx } x_{1 \mathrm{a}}, \quad s t x_{1 \mathrm{c}} \text {, } \\
s t x_{2 \mathrm{~b}}\end{array}$} \\
\hline & RM8760 & Sheep & \\
\hline & RM8763 & Sheep & \\
\hline & RM8778 & Sheep & \\
\hline & RM8923 & Cattle & \\
\hline & RM8929 & Sheep & \\
\hline & RM13865 & Cattle & \\
\hline O111:H8 & RM8755 & Sheep & $\begin{array}{l}\text { ent/espL2, espK, espN, } \\
\text { iha, nleA, nleB, nleE, } \\
\text { nleH1-2, sheA, stx 1a }\end{array}$ \\
\hline O146:H8 & RM8762 & Sheep & $\begin{array}{l}\text { iha, sheA, stx } x_{1 a}, s t x_{1 c} \\
s t x_{2 b}\end{array}$ \\
\hline \multirow[t]{2}{*}{ O146:H21 } & RM8756 & Sheep & \multirow{2}{*}{$\begin{array}{l}\text { iha, sheA, stx } 1 \mathrm{a}, s t x_{1 \mathrm{c}} \\
s t x_{2 \mathrm{~b}}\end{array}$} \\
\hline & RM8761 & Sheep & \\
\hline \multirow[t]{12}{*}{ O157:H7 } & RM8744 & Cattle & \multirow{12}{*}{$\begin{array}{l}\text { ent/espL2, espK, espN, } \\
\text { espP, etpD, iha, katP, nleA, } \\
\text { nleB, nleE, nleH1-2, sheA, } \\
\text { stx }_{2 \mathrm{c}}\end{array}$} \\
\hline & RM8753 & Sheep & \\
\hline & RM8759 & Sheep & \\
\hline & RM8768 & Cattle & \\
\hline & RM8781 & Sheep & \\
\hline & RM8922 & Cattle & \\
\hline & RM9450 & Sheep & \\
\hline & RM9452 & Sheep & \\
\hline & RM9454 & Cattle & \\
\hline & RM9456 & Cattle & \\
\hline & RM9458 & Chicken & \\
\hline & RM9462 & Cattle & \\
\hline
\end{tabular}

virulence determinants that were tested in the present study (Table 4).

\section{STX ACTIVITY IN STEC STRAINS ISOLATED FROM DOMESTIC FARM ANIMALS}

A quantitative and sensitive cell-based assay was further employed to examine the activity of the Stxs expressed by the O157 and non-O157 strains recovered from domestic animals in the Culiacan Valley. A Vero cell line, Vero-d2EGFP, was employed to measure the inhibition of protein synthesis by Stx in mammalian cells (Quiñones et al., 2009; Quiñones and Swimley, 2011). Consequently, incubation with active Stx results in a reduction of the EGFP fluorescent signal that is detected from the Vero-d2EGFP cells (Quiñones et al., 2009; Quiñones and Swimley, 2011). Our results indicated low levels of fluorescence, ranging from 5.4 to $19.5 \%$, were observed when the Verod2EGFP cells were incubated with culture supernatants from several STEC strains with the serotypes O8:H19, O75:H8, and O146:H8 (Figure 1), recovered from sheep and cattle. Further statistical analysis of the detected EGFP fluorescence indicated that these STEC strains with serotypes O8:H19, O75:H8 and O146:H8 belong to the same $k$-means cluster, suggesting that the Stx expressed by these non-O157 strains had similar effects on the EGFP fluorescence. Moreover, significantly reduced levels of EGFP fluorescence to approximately $16.7 \%$ were also observed after incubation with cell-free culture supernatants from the positive control O157:H7 strain RM2084 (Figure 1).

Intermediate levels of EGFP fluorescence, ranging from 22.9 to $32.4 \%$ were observed after incubation with culture supernatants from the ovine STEC strains belonging to serotypes O20:H4, O73:H4, O111:H8, and O146:H21. Interestingly, analysis of the culture supernatants from all O157:H7strains, recovered from sheep, cattle and chickens in the Culiacan Valley, resulted in significantly higher levels of EGFP fluorescence (Figure 1). The levels of EGFP fluorescence when testing the supernatants from the O157:H7 strains in the Vero-cell based assay ranged from 38.0 to $62.6 \%$. High levels of EGFP fluorescence that also belong to the same $k$-means cluster group as the O157:H7 strains were also observed when testing culture supernatants from the O15:NT and O73:NT strains (Figure 1). No reduction of EGFP fluorescence, averaging 98\% detected fluorescence, was observed after incubation with culture supernatants from the negative control O157:H4 strain RM8928 strain lacking an stx gene (Figure 1). The fluorescence in the Vero-d2EGFP cells still remained when testing culture supernatants from an stx-negative O157:H7 strain RM4876 (Quiñones et al., 2009) or after incubation with bacterial growth media without toxin added (data not shown).

\section{DISCUSSION}

In the present study, a genotyping and functional analysis was conducted to further characterize STEC strains, recovered from domestic animals in rural farms in the Culiacan Valley, which is considered one of the most important agricultural regions in Mexico (Amézquita-López et al., 2012). Given that the rural farms were located in communities that may not follow efficient management of animal wastes (Jiménez et al., 2011; Amézquita-López et al., 2012), an understanding of the virulence potential of the 


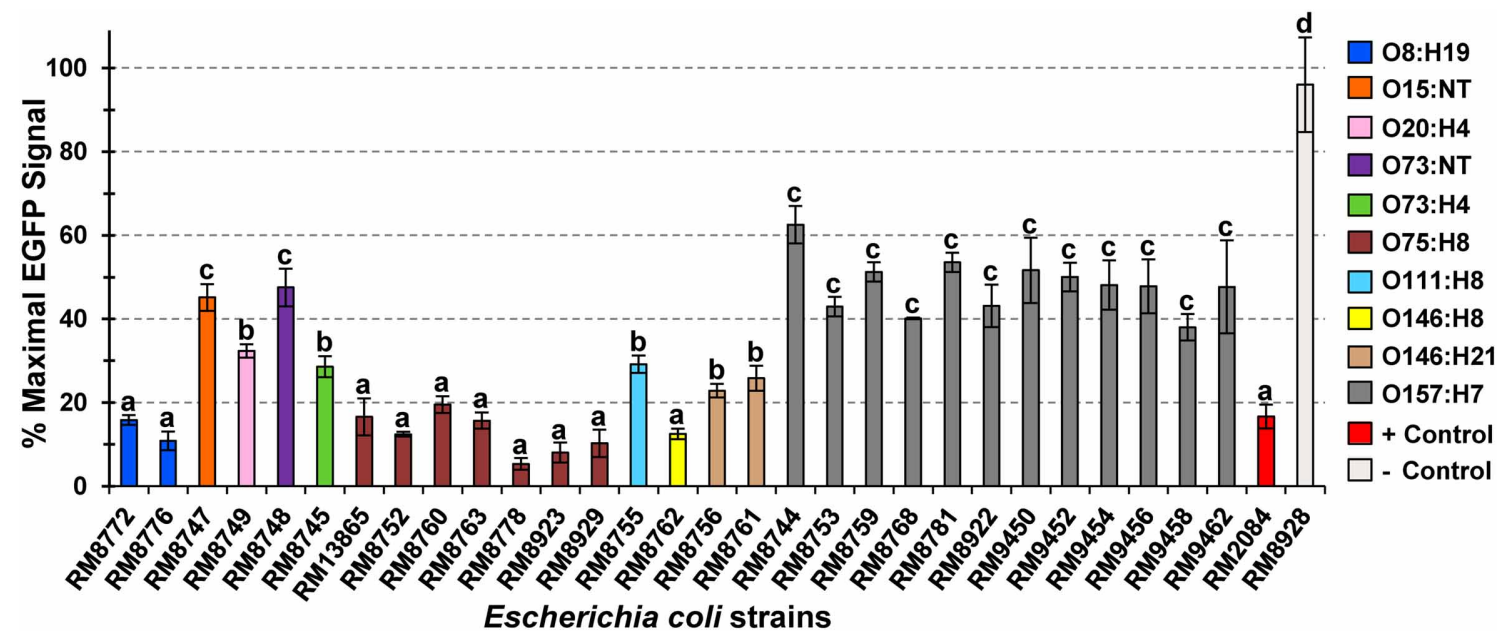

FIGURE 1 | Effect of Escherichia coli 0157 and non-0157 culture supernatants on Vero-d2EGFP fluorescence. Vero-d2EGFP cells were incubated in Ham's F-12 complete medium containing tenfold dilutions of cell-free culture supernatants from the tested Escherichia coli $\mathrm{O} 157$ and non-0157 strains (Table 1). Cell-free culture supernatants from the Stx-producing E. coli O157:H7 strain RM2084 and from the non-Stx producing E. coli O157:H4 strain RM8928 were used as positive and negative controls, respectively. The average \pm standard deviation of three independent experiments with duplicate samples for each strain is shown. Bars with the same lowercase letter represent significantly distinct clusters according to the $k$-means clustering algorithm and the $c /$ Valid $\mathrm{R}$ Software package (Brock et al., 2008; R-Core Team, 2013).
STEC strains recovered from animal reservoirs in this agricultural region would assist in the development of control measures to prevent the dispersal and transmission of pathogens throughout the environment that could lead to human infections associated with STEC.

The virulence typing analysis revealed that all O157:H7 and O111:H8 STEC strains from domestic animal reservoirs in the Culiacan Valley were positive for several of the nle genes, known to be located in the genomic islands OI-122 and OI-71 (Coombes et al., 2008). A previous study showed that these O157 and O111 STEC strains were also positive for eae (Amézquita-López et al., 2012). Thus, these findings revealed that these STEC strains from the Culiacan Valley harbor the gene signature, eae, ent/espL2, $n l e A, n l e B$, nleF, and nleH1-2, which has been proposed to be present in STEC strains with high virulence for humans (Bugarel et al., 2010a). Moreover, EtpD, the pO157 plasmid-encoded type II secretory pathway protein (Burland et al., 1998), was exclusively identified in O157:H7 strains. Finally, the STEC autoagglutinating adhesin (Saa) and subtilase cytotoxin (SubA) were specifically detected in the O8:H19 cattle strains, previously shown to be eaenegative and to display a limited genomic diversity by multiplelocus variable-number tandem repeat analysis (Amézquita-López et al., 2012). The findings from the present study are in agreement with other reports that documented Saa and SubA to be associated with non-O157 LEE-negative strains (Paton et al., 2001; Jenkins et al., 2003; Kumar et al., 2004; Toma et al., 2004; Zweifel et al., 2004; Kobayashi et al., 2013).

Approximately $79 \%$ of the $\mathrm{O} 157$ and non-O157 recovered STEC harbored both the iha and sheA genes. Previous studies demonstrated that iha, which codes for the iron-regulated gene A homolog adhesin, has been commonly observed in both LEE-positive as well as LEE-negative strains with different serotypes (Tarr et al., 2000; Schmidt et al., 2001). Moreover, sheA, encoding the cytolysin A or "silent hemolysin" has been shown to be prevalent in certain non-pathogenic E coli strains and in other enteropathogenic E. coli strains (Del Castillo et al., 1997; Fernández et al., 1998; Ludwig et al., 2004). All O157:H7 strains were positive for katP, a gene mostly identified in STEC strains belonging to seropathotypes associated with HUS (Bugarel et al., 2010b, 2011; Kobayashi et al., 2013). However, the present study also detected katP in O73:NT and O15:NT strains, belonging to serogroups not implicated in causing any human illness (Hussein, 2007).

To examine the relative toxicities of Stx subtypes expressed by the recovered STEC strains, the Vero-d2EGFP fluorescent assay was employed. The assay uses the Vero-d2EGFP cell line, expressing a destabilized variant of EGFP (Quiñones et al., 2009), and measures in mammalian cells the inhibition of protein synthesis by Stx (Quiñones et al., 2009; Quiñones and Swimley, 2011). Given that Vero cells are highly responsive to the effects of Stx (Keusch et al., 1995), the Vero-d2EGFP fluorescent assay is thus a sensitive and quantitative method to examine the potential relative toxicities of STEC strains. The results from the present study demonstrated that STEC strains with serotypes O8:H19, O75:H8, and $\mathrm{O} 146: \mathrm{H} 8$, serotypes previously associated with severe disease in humans (Boerlin et al., 1999; Blanco et al., 2003; Hussein, 2007), displayed a significant reduction in the EGFP signal from the Vero-d2EGFP cells to similar levels as the positive control O157:H7 strain RM2084. Moreover, the molecular typing study revealed that the $s t x$ gene profile $s t x_{1 \mathrm{a}}, s t x_{2 \mathrm{a}}$, and $s t x_{2 \mathrm{c}}$ was exclusively found in the O8:H19 cattle strains while the $s t x_{1 \mathrm{a}}, s t x_{1 \mathrm{c}}$, and $s t x_{2 b}$ profile was detected in the O73:H4, O75:H8, O146:H8 and O146:H21 strains from cattle and sheep. In summary, these findings have indicated that these non-O157 strains, possessing 
multiple stx subtypes, appear to be more efficient at inhibiting protein synthesis in mammalian cells.

Interestingly, analysis of the Stx activity from the $s t x_{2 c}$-positive O157:H7 strains, recovered from chicken, cattle, and sheep in the Culiacan Valley, indicated that the Vero-d2EGFP fluorescence levels were on average threefold higher when compared to the positive control O157:H7 strain RM2084. These findings suggested that the O157:H7 strains from this region in Mexico may have a significantly lower ability to inhibit protein synthesis in mammalian cells. Previous reports have documented that the Stx2a, Stx2c, and Stx2d subtypes have been associated with severe disease symptoms, including HUS and bloody diarrhea, as well as with differential toxicities in mammalian cells (Friedrich et al., 2002; Ethelberg et al., 2004; Persson et al., 2007; Manning et al., 2008; Müthing et al., 2009; Fuller et al., 2011; Quiñones and Swimley, 2011). However, recent evidence has indicated that purified Stx2c appears to have a reduced potency at inhibiting protein synthesis and metabolic activity in mammalian cells and a lower toxicity in mice (Fuller et al., 2011). The findings from the present study have demonstrated that the $s t x_{2 c}$-positive O157:H7 strains from this region in Mexico, previously shown to be closely-related by multiple-locus variable-number tandem repeat analysis (Amézquita-López et al., 2012), were less toxic to Vero cells although they possessed other key accessory virulence factors.

Previous reports have documented that the amounts of Stx2 produced may define the severity of disease caused by STEC strains (Zhang et al., 2000; Dean-Nystrom et al., 2003; Muniesa et al., 2004), and the differential expression and induction of Stx2 subtypes appears to contribute to the relative virulence of the STEC strain (Muniesa et al., 2004; Zhang et al., 2005; De Sablet et al., 2008). Therefore, future work is aimed at further characterizing the amounts of Stx produced after induction under different conditions to obtain a more detail understanding of the pathogenic potential of O157 and non-O157 STEC strains from diverse sampling sites and sampling sources in the agricultural Culiacan Valley region in Mexico.

\section{ACKNOWLEDGMENTS}

This work was supported by the USDA-Agricultural Research Service CRIS project number 5325-42000-047-00D and by a Postgraduate Studies Scholarship from The National Council of Science and Technology in Mexico (CONACyT grant \#234885) to Bianca A. Amézquita-López. The authors would like to thank Célida Martínez (CIAD in Culiacan, Sinaloa, Mexico) for excellent technical assistance.

\section{REFERENCES}

Amézquita-López, B. A., Quiñones, B., Cooley, M. B., León-Félix, J., CastroDel Campo, N., Mandrell, R. E., et al. (2012). Genotypic analyses of Shiga toxin-producing Escherichia coli $\mathrm{O} 157$ and non-O157 recovered from feces of domestic animals on rural farms in Mexico. PLoS ONE 7:e51565. doi: 10.1371/journal.pone.0051565

Bettelheim, K. A. (2007). The non-O157 Shiga-toxigenic (Verocytotoxigenic) Escherichia coli; under-rated pathogens. Crit. Rev. Microbiol. 33, 67-87. doi: 10.1080/10408410601172172

Beutin, L., Krause, G., Zimmermann, S., Kaulfuss, S., and Gleier, K. (2004). Characterization of Shiga toxin-producing Escherichia coli strains isolated from human patients in Germany over a 3-year period.
J. Clin. Microbiol. 42, 1099-1108. doi: 10.1128/JCM.42.3.1099-110 8.2004

Beutin, L., and Martin, A. (2012). Outbreak of Shiga toxin-producing Escherichia coli (STEC) O104:H4 infection in Germany causes a paradigm shift with regard to human pathogenicity of STEC strains. J. Food Prot. 75, 408-418. doi: 10.4315/0362-028X.JFP-11-452

Bielaszewska, M., Friedrich, A. W., Aldick, T., Schurk-Bulgrin, R., and Karch, H. (2006). Shiga toxin activatable by intestinal mucus in Escherichia coli isolated from humans: predictor for a severe clinical outcome. Clin. Infect. Dis. 43, 1160-1167. doi: 10.1086/508195

Blanco, M., Blanco, J. E., Mora, A., Rey, J., Alonso, J. M., Hermoso, M., et al. (2003). Serotypes, virulence genes, and intimin types of Shiga toxin (verotoxin)producing Escherichia coli isolates from healthy sheep in Spain. J. Clin. Microbiol. 41, 1351-1356. doi: 10.1128/JCM.41.4.1351-1356.2003

Boerlin, P., McEwen, S. A., Boerlin-Petzold, F., Wilson, J. B., Johnson, R. P., and Gyles, C. L. (1999). Associations between virulence factors of Shiga toxinproducing Escherichia coli and disease in humans. J. Clin. Microbiol. 37, 497-503.

Bolton, D. J. (2011). Verocytotoxigenic (Shiga toxin-producing) Escherichia coli: virulence factors and pathogenicity in the farm to fork paradigm. Foodborne Pathog. Dis. 8, 357-365. doi: 10.1089/fpd.2010.0699

Brock, G., Pihur, V., Datta, S., and Datta, S. (2008). clValid: an R package for cluster validation. J. Stat. Softw. 25, 1-22. Available online at: http://www.jstatsoft.org/ v25/i04/paper

Brooks, J. T., Sowers, E. G., Wells, J. G., Greene, K. D., Griffin, P. M., Hoekstra, R. M., et al. (2005). Non-O157 Shiga toxin-producing Escherichia coli infections in the United States, 1983-2002. J. Infect. Dis. 192, 1422-1429. doi: 10.1086/ 466536

Bugarel, M., Beutin, L., and Fach, P. (2010a). Low-density macroarray targeting non-locus of enterocyte effacement effectors (nle genes) and major virulence factors of Shiga toxin-producing Escherichia coli (STEC): a new approach for molecular risk assessment of STEC isolates. Appl. Environ. Microbiol. 76, 203-211. doi: 10.1128/AEM.01921-09

Bugarel, M., Beutin, L., Martin, A., Gill, A., and Fach, P. (2010b). Microarray for the identification of Shiga toxin-producing Escherichia coli (STEC) seropathotypes associated with Hemorrhagic Colitis and Hemolytic Uremic Syndrome in humans. Int. J. Food Microbiol. 142, 318-329. doi: 10.1016/j.ijfoodmicro.2010.07.010

Bugarel, M., Martin, A., Fach, P., and Beutin, L. (2011). Virulence gene profiling of enterohemorrhagic (EHEC) and enteropathogenic (EPEC) Escherichia coli strains: a basis for molecular risk assessment of typical and atypical EPEC strains. BMC Microbiol. 11:142. doi: 10.1186/1471-218011-142

Bürk, C., Dietrich, R., Acar, G., Moravek, M., Bulte, M., and Märtlbauer, E. (2003). Identification and characterization of a new variant of Shiga toxin 1 in Escherichia coli ONT:H19 of bovine origin. J. Clin. Microbiol. 41, 2106-2112. doi: 10.1128/JCM.41.5.2106-2112.2003

Burland, V., Shao, Y., Perna, N. T., Plunkett, G., Sofia, H. J., and Blattner, F. R. (1998). The complete DNA sequence and analysis of the large virulence plasmid of Escherichia coli O157:H7. Nucleic Acids Res. 26, 4196-4204. doi: 10.1093/nar/26.18.4196

Cooley, M. B., Jay-Russell, M., Atwill, E. R., Carychao, D., Nguyen, K., Quiñones, B., et al. (2013). Development of a robust method for isolation of Shiga toxin-positive Escherichia coli (STEC) from fecal, plant, soil and water samples from a leafy greens production region in California. PLOS ONE 8:e65716. doi: 10.1371/journal.pone.0065716

Cooley, M., Carychao, D., Crawford-Miksza, L., Jay, M. T., Myers, C., Rose, C., et al. (2007). Incidence and tracking of Escherichia coli O157:H7 in a major produce production region in California. PLoS ONE 2:e1159. doi: 10.1371/journal.pone.0001159

Coombes, B. K., Gilmour, M. W., and Goodman, C. D. (2011). The evolution of virulence in non-O157 Shiga toxin-producing Escherichia coli. Front. Microbiol. 2:90. doi: 10.3389/fmicb.2011.00090

Coombes, B. K., Wickham, M. E., Mascarenhas, M., Gruenheid, S., Finlay, B. B., and Karmali, M. A. (2008). Molecular analysis as an aid to assess the public health risk of non-O157 Shiga toxin-producing Escherichia coli strains. Appl. Environ. Microbiol. 74, 2153-2160. doi: 10.1128/AEM.02566-07

Dean-Nystrom, E. A., Melton-Celsa, A. R., Pohlenz, J. F., Moon, H. W., and O'Brien, A. D. (2003). Comparative pathogenicity of Escherichia coli $\mathrm{O} 157$ and 
intimin-negative non-O157 Shiga toxin-producing $E$ coli strains in neonatal pigs. Infect. Immun. 71, 6526-6533. doi: 10.1128/IAI.71.11.6526-6533.2003

Del Castillo, F. J., Leal, S. C., Moreno, F., and Del Castillo, I. (1997). The Escherichia coli K-12 sheA gene encodes a 34-kDa secreted haemolysin. Mol. Microbiol. 25, 107-115. doi: 10.1046/j.1365-2958.1997.4391813.x

De Sablet, T., Bertin, Y., Vareille, M., Girardeau, J. P., Garrivier, A., Gobert, A. P., et al. (2008). Differential expression of $s t x_{2}$ variants in Shiga toxinproducing Escherichia coli belonging to seropathotypes A and C. Microbiology 154, 176-186. doi: 10.1099/mic.0.2007/009704-0

Ethelberg, S., Olsen, K. E., Scheutz, F., Jensen, C., Schiellerup, P., Enberg, J., et al. (2004). Virulence factors for hemolytic uremic syndrome, Denmark. Emerg. Infect. Dis. 10, 842-847. doi: 10.3201/eid1005.030576

Feng, P. C., Jinneman, K., Scheutz, F., and Monday, S. R. (2011). Specificity of PCR and serological assays in the detection of Escherichia coli Shiga toxin subtypes. Appl. Environ. Microbiol. 77, 6699-6702. doi: 10.1128/AEM. 00370-11

Ferens, W. A., and Hovde, C. J. (2011). Escherichia coli O157:H7: animal reservoir and sources of human infection. Foodborne Pathog. Dis. 8, 465-487. doi: 10.1089/fpd.2010.0673

Fernández, S. V., Xing, J., Kapur, V., Libby, S. J., Barletta, R. G., and Moxley, R. A. (1998). Regulation of the Escherichia coli sheA gene and characterization of its encoded hemolytic activity. FEMS Microbiol. Lett. 168, 85-90. doi: 10.1016/S0378-1097(98)00413-3

Friedrich, A. W., Bielaszewska, M., Zhang, W. L., Pulz, M., Kuczius, T., Ammon, A., et al. (2002). Escherichia coli harboring Shiga toxin 2 gene variants: frequency and association with clinical symptoms. J. Infect. Dis. 185, 74-84. doi: 10.1086/338115

Friedrich, A. W., Borell, J., Bielaszewska, M., Fruth, A., Tschape, H., and Karch, H. (2003). Shiga toxin 1c-producing Escherichia coli strains: phenotypic and genetic characterization and association with human disease. J. Clin. Microbiol. 41, 2448-2453. doi: 10.1128/JCM.41.6.2448-2453.2003

Fuller, C. A., Pellino, C. A., Flagler, M. J., Strasser, J. E., and Weiss, A. A. (2011). Shiga toxin subtypes display dramatic differences in potency. Infect. Immun. 79, 1329-1337. doi: 10.1128/IAI.01182-10

Gould, L. H., Bopp, C., Strockbine, N., Atkinson, R., Baselski, V., Body, B., et al. (2009). Recommendations for diagnosis of Shiga toxin-producing Escherichia coli infections by clinical laboratories. MMWR Recomm. Rep. 58, 1-14. Available online at: http://www.cdc.gov/mmwr/preview/mmwrhtml/rr5812a1.htm

Gyles, C. L. (2007). Shiga toxin-producing Escherichia coli: an overview. J. Anim. Sci. 85, E45-E62. doi: 10.2527/jas.2006-508

Hartigan, J. A., and Wong, M. A. (1979). Algorithm AS 136: a $k$-means clustering algorithm. Appl. Stat. 28, 100-108. doi: 10.2307/2346830

Hoefer, D., Hurd, S., Medus, C., Cronquist, A., Hanna, S., Hatch, J., et al. (2011). Laboratory practices for the identification of Shiga toxin-producing Escherichia coli in the United States, FoodNet sites, 2007. Foodborne Pathog. Dis. 8, 555-560. doi: 10.1089/fpd.2010.0764

Hussein, H. S. (2007). Prevalence and pathogenicity of Shiga toxin-producing Escherichia coli in beef cattle and their products. J. Anim. Sci. 85, E63-72. doi: 10.2527/jas.2006-421

Ito, H., Terai, A., Kurazono, H., Takeda, Y., and Nishibuchi, M. (1990). Cloning and nucleotide sequencing of Vero toxin 2 variant genes from Escherichia coli O91:H21 isolated from a patient with the hemolytic uremic syndrome. Microb. Pathog. 8, 47-60. doi: 10.1016/0882-4010(90) 90007-D

Jenkins, C., Perry, N. T., Cheasty, T., Shaw, D. J., Frankel, G., Dougan, G., et al. (2003). Distribution of the saa gene in strains of Shiga toxin-producing Escherichia coli of human and bovine origins. J. Clin. Microbiol. 41, 1775-1778. doi: 10.1128/JCM.41.4.1775-1778.2003

Jerse, A. E., Yu, J., Tall, B. D., and Kaper, J. B. (1990). A genetic locus of enteropathogenic Escherichia coli necessary for the production of attaching and effacing lesions on tissue culture cells. Proc. Natl. Acad. Sci. U.S.A. 87, 7839-7843. doi: 10.1073/pnas.87.20.7839

Jiménez, M., Martínez-Urtaza, J., and Chaidez, C. (2011). Geographical and temporal dissemination of salmonellae isolated from domestic animal hosts in the Culiacan Valley, Mexico. Microb. Ecol. 61, 811-820. doi: 10.1007/s00248-0109792-5

Johnson, K. E., Thorpe, C. M., and Sears, C. L. (2006). The emerging clinical importance of non-O157 Shiga toxin-producing Escherichia coli. Clin. Infect. Dis. 43, 1587-1595. doi: 10.1086/509573
Kaper, J. B. (1998). The locus of enterocyte effacement pathogenicity island of Shiga toxin-producing Escherichia coli O157:H7 and other attaching and effacing E. coli. Jpn. J. Med. Sci. Biol. 51(Suppl.), S101-S107.

Karmali, M. A. (1989). Infection by verocytotoxin-producing Escherichia coli. Clin. Microbiol. Rev. 2, 15-38.

Karmali, M. A. (2009). Host and pathogen determinants of verocytotoxinproducing Escherichia coli-associated hemolytic uremic syndrome. Kidney Int. Suppl. 75, S4-S7. doi: 10.1038/ki.2008.608

Karmali, M. A., Gannon, V., and Sargeant, J. M. (2010). Verocytotoxinproducing Escherichia coli (VTEC). Vet. Microbiol. 140, 360-370. doi: 10.1016/j.vetmic.2009.04.011

Karmali, M. A., Steele, B. T., Petric, M., and Lim, C. (1983). Sporadic cases of haemolytic-uraemic syndrome associated with faecal cytotoxin and cytotoxinproducing Escherichia coli in stools. Lancet 321, 619-620. doi: 10.1016/S01406736(83)91795-6

Kerényi, M., Allison, H. E., Bátai, I., Sonnevend, Á., Emödy, L., Plaveczky, N. et al. (2005). Occurrence of $h l y A$ and sheA genes in extraintestinal Escherichia coli strains. J. Clin. Microbiol. 43, 2965-2968. doi: 10.1128/JCM.43.6.29652968.2005

Keusch, G. T., Jacewicz, M., Acheson, D. W., Donohue-Rolfe, A., Kane, A. V., and McCluer, R. H. (1995). Globotriaosylceramide, Gb3, is an alternative functional receptor for Shiga-like toxin 2e. Infect. Immun. 63, 1138-1141.

Kobayashi, N., Lee, K. I., Yamazaki, A., Saito, S., Furukawa, I., Kono, T., et al. (2013). Virulence gene profiles and population genetic analysis for exploration of pathogenic serogroups of Shiga toxin-producing Escherichia coli. J. Clin. Microbiol. 51, 4022-4028 doi: 10.1128/JCM.01598-13

Koch, C., Hertwig, S., Lurz, R., Appel, B., and Beutin, L. (2001). Isolation of a lysogenic bacteriophage carrying the $s x_{10 X 3}$ gene, which is closely associated with Shiga toxin-producing Escherichia coli strains from sheep and humans. J. Clin. Microbiol. 39, 3992-3998. doi: 10.1128/JCM.39.11.39923998.2001

Kumar, H. S., Karunasagar, I., Teizou, T., Shima, K., and Yamasaki, S. (2004). Characterisation of Shiga toxin-producing Escherichia coli (STEC) isolated from seafood and beef. FEMS Microbiol. Lett. 233, 173-178. doi: 10.1016/j.femsle.2004.02.008

Kyle, J. L., Cummings, C. A., Parker, C. T., Quinones, B., Vatta, P., Newton, E., et al. (2012). Escherichia coli serotype O55:H7 diversity supports parallel acquisition of bacteriophage at Shiga toxin phage insertion sites during evolution of the O157:H7 lineage. J. Bacteriol. 194, 1885-1896. doi: 10.1128/JB. 00120-12

La Ragione, R. M., Best, A., Woodward, M. J., and Wales, A. D. (2009). Escherichia coli O157:H7 colonization in small domestic ruminants. FEMS Microbiol. Rev. 33, 394-410. doi: 10.1111/j.1574-6976.2008.00138.x

Leung, P. H., Peiris, J. S., Ng, W. W., Robins-Browne, R. M., Bettelheim, K. A., and Yam, W. C. (2003). A newly discovered verotoxin variant, VT2g, produced by bovine verocytotoxigenic Escherichia coli. Appl. Environ. Microbiol. 69, 7549-7553. doi: 10.1128/AEM.69.12.75497553.2003

Ludwig, A., Von Rhein, C., Bauer, S., Hüttinger, C., and Goebel, W. (2004) Molecular analysis of cytolysin A (ClyA) in pathogenic Escherichia coli strains. J. Bacteriol. 186, 5311-5320. doi: 10.1128/JB.186.16.5311-5320.2004

Mandrell, R. E. (2011). "Tracing pathogens in fruit and vegetable production chains," in Tracing Pathogens in the Food Chain, eds S. Brul, P. M. Fratamico, and T. McMeekin (Philadelphia, PA: Woodhead Publishing), 548-595. doi: 10.1533/9780857090508.4.548

Manning, S. D., Motiwala, A. S., Springman, A. C., Qi, W., Lacher, D. W., Ouellette, L. M., et al. (2008). Variation in virulence among clades of Escherichia coli O157:H7 associated with disease outbreaks. Proc. Natl. Acad. Sci. U.S.A. 105, 4868-4873. doi: 10.1073/pnas.0710834105

Mathusa, E. C., Chen, Y., Enache, E., and Hontz, L. (2010). Non-O157 Shiga toxinproducing Escherichia coli in foods. J. Food Prot. 73, 1721-1736. Available online at: http://www.ncbi.nlm.nih.gov/pubmed/20828483

Melton-Celsa, A., Mohawk, K., Teel, L., and O’Brien, A. (2012). Pathogenesis of Shiga-toxin producing Escherichia coli. Curr. Top. Microbiol. Immunol. 357, 67-103. doi: 10.1007/82_2011_176

Muniesa, M., Blanco, J. E., De Simón, M., Serra-Moreno, R., Blanch, A. R., and Jofre, J. (2004). Diversity of stx 2 converting bacteriophages induced from Shigatoxin-producing Escherichia coli strains isolated from cattle. Microbiology 150, 2959-2971. doi: 10.1099/mic.0.27188-0 
Müthing, J., Schweppe, C. H., Karch, H., and Friedrich, A. W. (2009). Shiga toxins, glycosphingolipid diversity, and endothelial cell injury. Thromb. Haemost. 101, 252-264. doi: 10.1160/TH08-05-0317

Nakao, H., Kimura, K., Murakami, H., Maruyama, T., and Takeda, T. (2002). Subtyping of Shiga toxin 2 variants in human-derived Shiga toxin-producing Escherichia coli strains isolated in Japan. FEMS Immunol. Med. Microbiol. 34, 289-297. doi: 10.1111/j.1574-695X.2002.tb00636.x

Ogden, I. D., Macrae, M., and Strachan, N. J. (2005). Concentration and prevalence of Escherichia coli $\mathrm{O} 157$ in sheep faeces at pasture in Scotland. J. Appl. Microbiol. 98, 646-651. doi: 10.1111/j.1365-2672.2004.02493.x

Paton, A. W., Srimanote, P., Woodrow, M. C., and Paton, J. C. (2001). Characterization of Saa, a novel autoagglutinating adhesin produced by locus of enterocyte effacement-negative Shiga-toxigenic Escherichia coli strains that are virulent for humans. Infect. Immun. 69, 6999-7009. doi: 10.1128/IAI.69.11.6999-7009.2001

Persson, S., Olsen, K. E., Ethelberg, S., and Scheutz, F. (2007). Subtyping method for Escherichia coli shiga toxin (verocytotoxin) 2 variants and correlations to clinical manifestations. J. Clin. Microbiol. 45, 2020-2024. doi: 10.1128/JCM. 02591-06

Piérard, D., Muyldermans, G., Moriau, L., Stevens, D., and Lauwers, S. (1998). Identification of new verocytotoxin type 2 variant B-subunit genes in human and animal Escherichia coli isolates. J. Clin. Microbiol. 36, 3317-3322.

Quiñones, B., Massey, S., Friedman, M., Swimley, M. S., and Teter, K. (2009). Novel cell-based method to detect Shiga toxin 2 from Escherichia coli O157:H7 and inhibitors of toxin activity. Appl. Environ. Microbiol. 75, 1410-1416. doi: 10.1128/AEM.02230-08

Quiñones, B., and Swimley, M. S. (2011). Use of a Vero cell-based fluorescent assay to assess relative toxicities of Shiga toxin 2 subtypes from Escherichia coli. Methods Mol. Biol. 739, 61-71. doi: 10.1007/978-1-61779-102-4_6

Quiñones, B., Swimley, M. S., Narm, K.-E., Patel, R. N., Cooley, M. B., and Mandrell, R. E. (2012). O-antigen and virulence profiling of Shiga toxinproducing Escherichia coli by a rapid and cost-effective DNA microarray colorimetric method. Front. Cell. Inf. Microbiol. 2:61. doi: 10.3389/fcimb.2012.00061

Quiñones, B., Swimley, M. S., Taylor, A. W., and Dawson, E. D. (2011). Identification of Escherichia coli $\mathrm{O} 157$ by using a novel colorimetric detection method with DNA microarrays. Foodborne Pathog. Dis. 8, 705-711. doi: $10.1089 /$ fpd.2010.0753

R-Core Team. (2013). R Foundation for Statistical Computing. (Vienna: R: a language and environment for statistical computing). Available online at: http:// www.R-project.org

Reid, S. D., Betting, D. J., and Whittam, T. S. (1999). Molecular detection and identification of intimin alleles in pathogenic Escherichia coli by multiplex PCR J. Clin. Microbiol. 37, 2719-2722.

Scallan, E., Hoekstra, R. M., Angulo, F. J., Tauxe, R. V., Widdowson, M. A., Roy, S. L., et al. (2011). Foodborne illness acquired in the United States-major pathogens. Emerg. Infect. Dis. 17, 7-15. doi: 10.3201/eid1701.091101p1

Scheutz, F., and Strockbine, N. A. (2005). "Genus I. Escherichia.," in Bergey's Manual of Systematic Bacteriology, eds G. M. Garrity, D. J. Brenner, N. R. Krieg and J. T. Staley (New York, NY: Springer), 607-624.

Scheutz, F., Teel, L. D., Beutin, L., Piérard, D., Buvens, G., Karch, H., et al. (2012). Multicenter evaluation of a sequence-based protocol for subtyping Shiga toxins and standardizing Stx nomenclature. J. Clin. Microbiol. 50, 2951-2963. doi: 10.1128/JCM.00860-12

Schmidt, H., Zhang, W. L., Hemmrich, U., Jelacic, S., Brunder, W., Tarr, P. I., et al. (2001). Identification and characterization of a novel genomic island integrated at selC in locus of enterocyte effacement-negative, Shiga toxin-producing Escherichia coli. Infect. Immun. 69, 6863-6873. doi: 10.1128/IAI.69.11.68636873.2001
Schmitt, C. K., McKee, M. L., and O'Brien, A. D. (1991). Two copies of Shiga-like toxin II-related genes common in enterohemorrhagic Escherichia coli strains are responsible for the antigenic heterogeneity of the O157:H- strain E32511. Infect. Immun. 59, 1065-1073.

Stigi, K. A., Macdonald, J. K., Tellez-Marfin, A. A., and Lofy, K. H. (2012). Laboratory practices and incidence of non-O157 Shiga toxinproducing Escherichia coli infections. Emerg. Infect. Dis. 18, 477-479. doi: 10.3201/eid1803.111358

Tarr, P. I., Bilge, S. S., Vary, J. C. Jr., Jelacic, S., Habeeb, R. L., Ward, T. R., et al. (2000). Iha: a novel Escherichia coli O157:H7 adherence-conferring molecule encoded on a recently acquired chromosomal island of conserved structure. Infect. Immun. 68, 1400-1407. doi: 10.1128/IAI.68.3.1400-1407.2000

Tarr, P. I., Gordon, C. A., and Chandler, W. L. (2005). Shiga-toxin-producing Escherichia coli and haemolytic uraemic syndrome. Lancet 365, 1073-1086. doi: 10.1016/S0140-6736(05)71144-2

Toma, C., Martinez Espinosa, E., Song, T., Miliwebsky, E., Chinen, I., Iyoda, S., et al. (2004). Distribution of putative adhesins in different seropathotypes of Shiga toxin-producing Escherichia coli. J. Clin. Microbiol. 42, 4937-4946. doi: 10.1128/JCM.42.11.4937-4946.2004

Weinstein, D. L., Jackson, M. P., Samuel, J. E., Holmes, R. K., and O’Brien, A. D. (1988). Cloning and sequencing of a Shiga-like toxin type II variant from Escherichia coli strain responsible for edema disease of swine. J. Bacteriol. 170, 4223-4230.

Zhang, W., Bielaszewska, M., Friedrich, A. W., Kuczius, T., and Karch, H. (2005). Transcriptional analysis of genes encoding Shiga toxin 2 and its variants in Escherichia coli. Appl. Environ. Microbiol. 71, 558-561. doi: 10.1128/AEM.71.1.558-561.2005

Zhang, X., McDaniel, A. D., Wolf, L. E., Keusch, G. T., Waldor, M. K., and Acheson, D. W. (2000). Quinolone antibiotics induce Shiga toxin-encoding bacteriophages, toxin production, and death in mice. J. Infect. Dis. 181, 664-670. doi: $10.1086 / 315239$

Zheng, J., Cui, S., Teel, L. D., Zhao, S., Singh, R., O’Brien, A. D., et al. (2008). Identification and characterization of Shiga toxin type 2 variants in Escherichia coli isolates from animals, food, and humans. Appl. Environ. Microbiol. 74, 5645-5652. doi: 10.1128/AEM.00503-08

Zweifel, C., Blanco, J. E., Blanco, M., Blanco, J., and Stephan, R. (2004) Serotypes and virulence genes of ovine non-O157 Shiga toxin-producing Escherichia coli in Switzerland. Int. J. Food Microbiol. 95, 19-27. doi: 10.1016/j.ijfoodmicro.2004.01.015

Conflict of Interest Statement: The authors declare that the research was conducted in the absence of any commercial or financial relationships that could be construed as a potential conflict of interest.

Received: 29 July 2013; paper pending published: 20 August 2013; accepted: 13 January 2014; published online: 31 January 2014.

Citation: Amézquita-López BA, Quiñones B, Lee BG and Chaidez C (2014) Virulence profiling of Shiga toxin-producing Escherichia coli recovered from domestic farm animals in Northwestern Mexico. Front. Cell. Infect. Microbiol. 4:7. doi: 10.3389/fcimb. 2014.00007

This article was submitted to the journal Frontiers in Cellular and Infection Microbiology.

Copyright (C) 2014 Amézquita-López, Quiñones, Lee and Chaidez. This is an openaccess article distributed under the terms of the Creative Commons Attribution License (CC BY). The use, distribution or reproduction in other forums is permitted, provided the original author(s) or licensor are credited and that the original publication in this journal is cited, in accordance with accepted academic practice. No use, distribution or reproduction is permitted which does not comply with these terms. 